\title{
The Graduate Research Report
}

\section{Recent Dissertations}

Berry-Hillman, P. Jung's early psychiatric writing: the emergence of a psychopoetics. University of Dallas.

Douglas, C. Analytical psychology and the feminine. Saybrook Institute.

Eisenshtadt, J. H. An investigation of the relationship between adult men and their fathers: A phenomenological study. Saybrook Institute.

Gaine, D. Mind/body/spirit connection: The psychophysiological effects of hypnosis and relaxation response. The University for Humanistic Studies.

Gerwin, D. Therapeutic of Proteus: Goethe, Coleridge, and a polar 'new physics' phychology of eye and ear. University of Dallas.

Hesky, S. Effective and ineffective personal insight: An empirical phenomenological investigation. Duquesne University.

Holtz, V. Being disillusioned: An empirical phenomenological investigation. Duquesne University.

Kessler, B. Personal meanings of bereavement. Saybrook Institute.

Moss, D. Transformations in embodied existence following intestinal bypass surgery. Duquesne University.

Nevins, C. K. Transitions of the self prompted by critical events. Saybrook Institute.

Sadowsky, S. An empirical phenomenological investigation of being resentful. Duquesne University.

Wells, R. A. Between earth and sky: Towards a psychology of homecoming. University of Dallas.

\section{Graduate Student News}

The revised edition of Division 32's Directory of Graduate Programs in Humanistic and Transpersonal Psychology is now available for $\$ 4.00$ a copy from: Mike Arons, Psychology Dept., West Georgia College, Carrollton, GA 30118.

Graduate students are urged to apply for the Division 32 Student Paper Award. The winning student will be given the opportunity to present the paper at the 1986 APA convention, with possible publication in The Humanistic Psychologist. Applicants should send three copies of their paper to: Chris Aanstoos, Psychology Dept., West Georgia College, Carrollton, GA 30118. 